\title{
A FACILITY LAYOUT PROBLEM IN A MARBLE FACTORY VIA SIMULATION
}

\author{
Rahime Sancar Edis ${ }^{1}$, Bayram Kahraman ${ }^{2}$, Özlem Uzun Araz ${ }^{3}$, M. Kemal Özfırat ${ }^{2}$ * \\ ${ }^{1}$ Department of Industrial Engineering, Erciyes University, Melikgazi, Kayseri, Turkey \\ ${ }^{2}$ Department of Mining Engineering, Dokuz Eylül University, Buca, İzmir, Turkey \\ ${ }^{3}$ Department of Industrial Engineering, Celal Bayar University, Muradiye, Manisa, \\ Turkey \\ *kemal.ozfirat@deu.edu.tr
}

\begin{abstract}
The marble factory in this study is a typical instance of a flow shop based production system. Adding new machines to the plant and/or introducing a new product may convert the actual layout to an inefficient one. Such cases may cause a significant increase in transportation of materials between machines that decreases the utilization rates of machines and operators as well as overall productivity. Therefore, facility planning is a key issue in marble plants in terms of total cost and customer satisfaction. Another important property of these plants is its dynamic and stochastic behavior in terms of scrap rates, demands and processing times. The aim of this study is to develop an efficient plant layout for such dynamic systems. At first, the simulation model of the current system is built on ARENA 10.0. Then, an alternative layout is generated after some analysis and then, it is evaluated via simulation model. The proposed layout provides reduction in total transportation time as well as an increase in productivity.
\end{abstract}

Key Words- Marble Factory, Facility layout, Simulation.

\section{INTRODUCTION}

Turkey is one of the leading countries in re-crystallized limestone and travertine reserves. According to 2003 data, Turkey has exported 1400000 tons of marble blocks in return of 106 million US\$s and 799102 tons of finished marble products in return of 323 million US\$s [1]. Having 40\% of marble reserves of all the world, Turkey is on the way to become to largest marble exporter of the world. In 1980, natural stone exports were 2 million US\$. In 2006, this number has become 1 billion 27 million US\$ and the volume of exports has increased 500 times.

Since marble has a great importance in export economy, the problems of marble factories have to be solved to increase productivity and decrease costs. Marble blocks produced from marble quarries are cut, polished and turned into marble products in marble processing factories. Some of the marble processing factories only produce marble planes or strips, whereas others produce final marble products. Factories producing marble planes have gangsaw machines or ST machines in order cut marble block into marble planes. The marble factories producing final marble products supplies marble planes (in different dimensions) from first group marble factories, then cuts these planes into final products in smaller dimensions (length $30,5 \mathrm{~cm}$; thickness $2-3 \mathrm{~cm}$, width $4-7 \mathrm{~cm})$. 
The layouts of marble factories are generally made according to flow shop production systems. The layout changes with the introduction of new machines or new products. However, new machines are put to the free spaces without considering relocating the departments. In new product case, the flow of new products may be different than the current products. The layouts made without considering the affect of introducing new machines or products may cause larger transportation times between departments. Again, the facility layout problem arises. The facility layout can be defined as a plan of an optimum arrangement of departments, personal, equipments and storage spaces to design the best structure of the facility.

There are some types of layouts such as product layout, process layout, and fixed layout. Product type of layout is generally appropriate for the facilities which produce one product or one type of a product. Therefore, the machines (or departments) are configured as in the order of operations of the product. In process type layout, the machines that perform similar operations are grouped together. The products visit these groups in the order of their operations. In case of fixed type layout, the products and their components are placed in a fixed location and the labor, equipment or tools are brought to this location. ([2])

The layout problem may be stimulated by cost reductions, production design change, new product introduction and changes in demands [2]. According to these changes, the layout problem may arise to perform minor changes in the present layout, rearrangement of the current layout, relocating into existing facilities or building a new plant.

The objectives of the facility layout problems can be listed as; [2].

- To provide overall simplification

- To minimize material handling

- To provide high work-in-progress turnover

- To provide effective space utilization

- To stimulate effective labor utilization

- To avoid unnecessary capital investment

- To provide worker convenience and job satisfaction

The managers often minimize the material handling cost associated with the layout, since the cost of material handling accounts for $30 \%$ to $95 \%$ of the total production cost. Usually this cost is proportional to the distance moved. ([2])

The basic data to analyze the flow of materials is the order of operations of the products, i.e., routings. The flow of material analysis is the most important issue in layout planning where the movement of materials is a major portion of the process. ([2])

In the literature, there are so many study related to facility layout problem. The facility layout problem is surveyed by [3]. They give various formulations of layout problems and algorithms to solve these problems. Some heuristic approaches are also applied to facility layout problem $[4,5]$. Some researchers [6-8] tried to solve the facility layout problem with meta-heuristics. Reference [9] summarizes the main 
characteristics of the most-used solution procedures for the facility layout problem. Lastly, the recent challenges in factory layouts are discussed by [10].

In the next section, the facility layout problem in a marble factory is described. In Section 3, the analyses are carried out and an alternative layout is proposed. Also, the current and proposed layouts are compared in this section. Section 4 summarizes the study.

\section{PROBLEM CHARACTERISTICS}

Marble planes supplied from surrounding marble factories are used to produce five different products namely, A, B, C, D, and E. The geometric views and the dimensions of products are given in Figure 1.

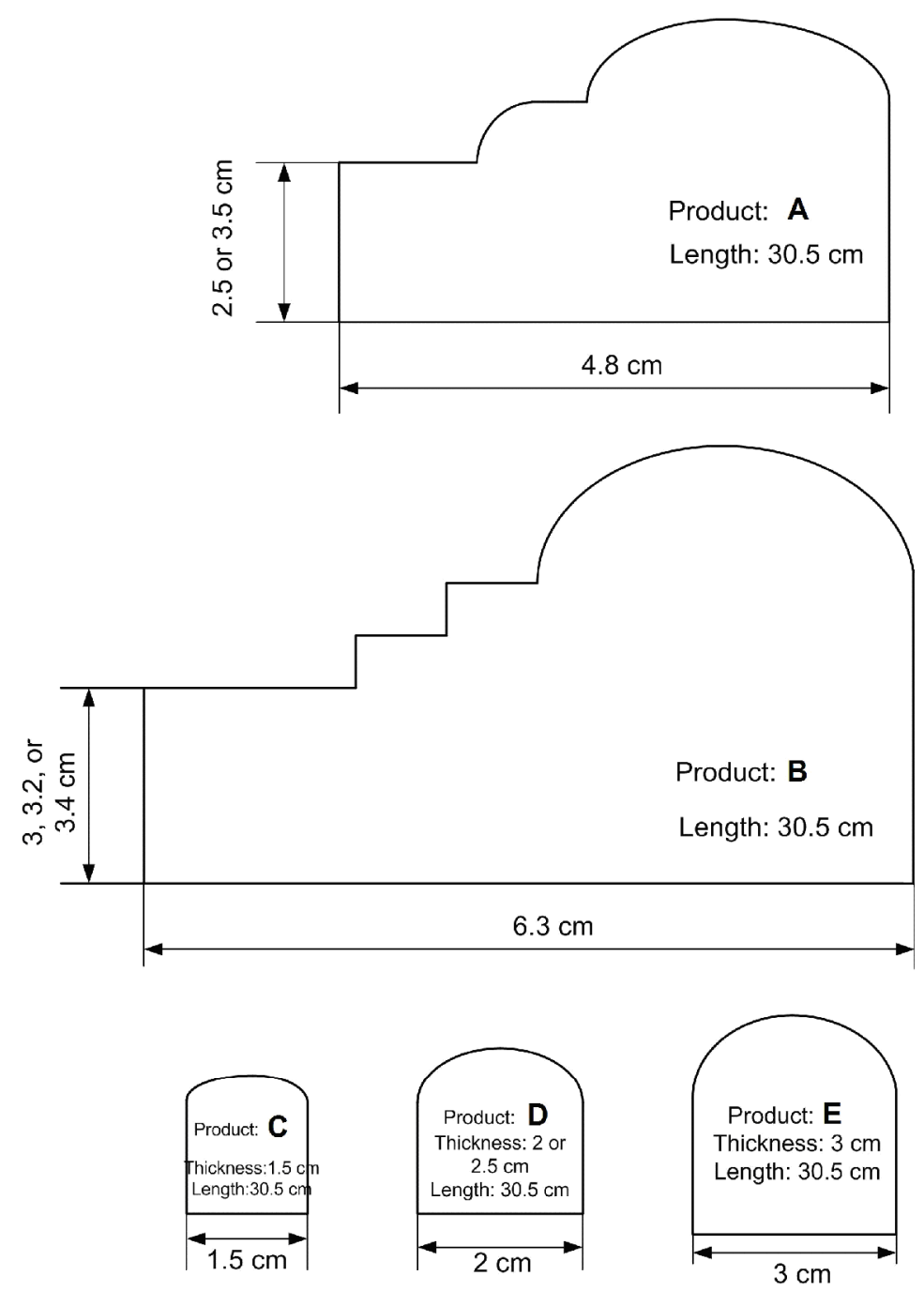

Figure 1. The shapes of the products 
The production steps of the products are given in Figure 2. The shapes and dimensions of the marble plates are not same all the time. If the required thickness of the product is smaller than the thickness of the marble plate, so an operation named horizontal cutting have to be performed to reduce the thickness of the raw materials (i.e., marble plates). If the length of the marble plate is long enough to get more than one product, side cutting operation should be performed to cut the marble plate into products. The production steps of the products are generally same for all product types.

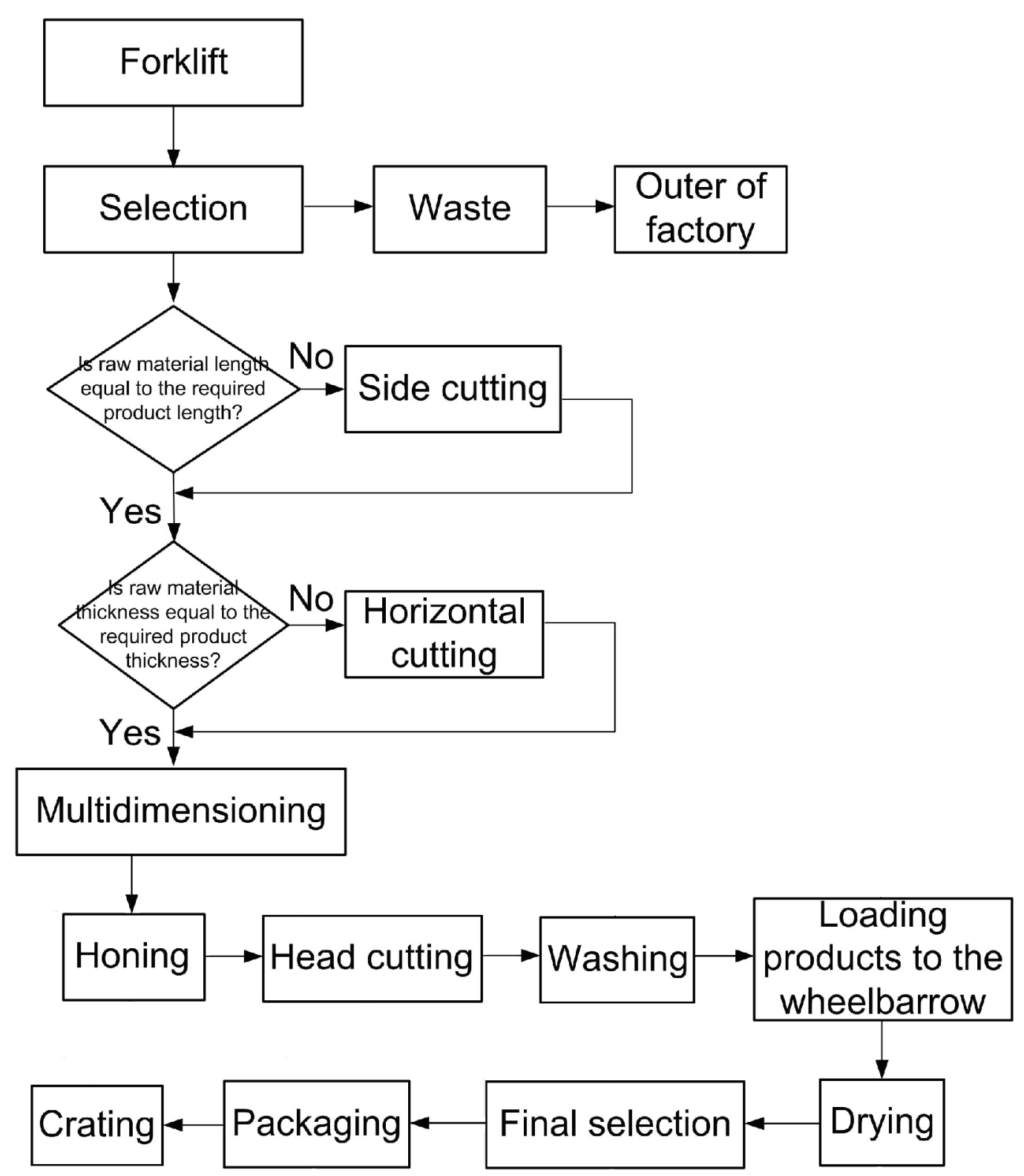

Figure 2. Operation flow chart

As seen in Figure 2, raw materials placed on a pallet are moved to selection area with a forklift. After the selection operation, spoiled raw material is moved to spoilage without entering the factory. Afterwards, products which are already in right dimensions 
are moved to multi dimensioning machine whereas, others are moved first to side cutting and then to multi dimensioning machine. At this step, raw materials which are more than $3 \mathrm{~cm}$ thick go through horizontal cutting operation and their thicknesses are decreased to be less than $3 \mathrm{~cm}$. After these operations, products go through three headed or four headed honing machines to be cut according to their geometric shapes. Finally, these products are washed and dried. After drying operation, products in the wheelbarrow are moved to final selection area. In this area, products go through another selection operation. The qualified ones are packaged and become ready for sale. Products are transferred one by one between operations except from the entrance to the selection operation.

The current layout of the factory is given in Figure 3. At first, the production area is analyzed and the data is collected. The processing times of each product on each operation, the demands of products, the arrival rate of the demands are calculated by fitting the appropriate distributions. The Input Analyzer module of the ARENA 10.0 [11] is used for these calculations. These data is important for the modeling part of the production area and to compare the proposed and current layout performances. Then the simulation model of the factory is built in ARENA 10.0 [11] software package. The validation and verification of the model is done.

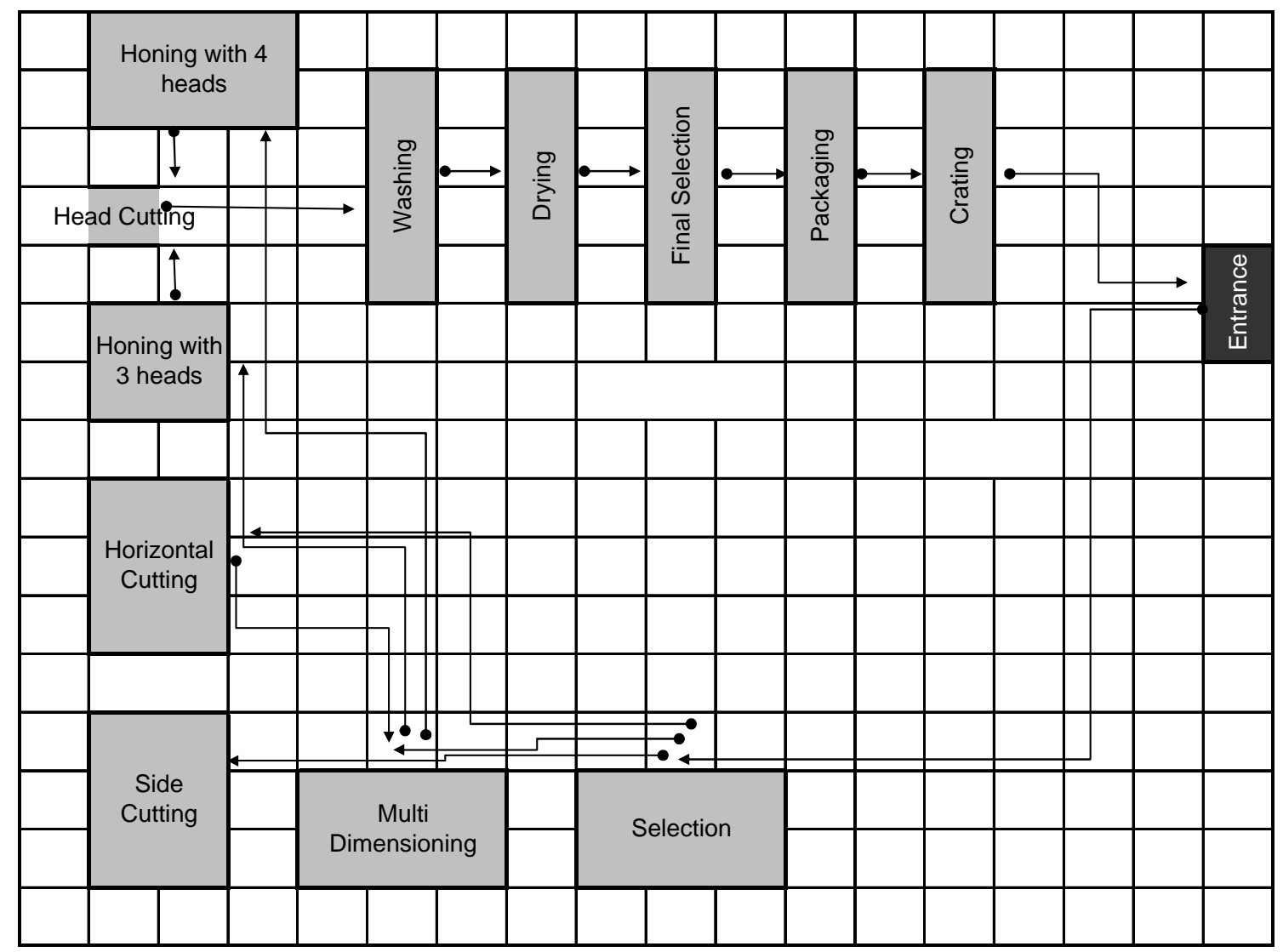

Figure 3. Current layout of departments 


\section{PROPOSED LAYOUT}

The relationships of the departments are analyzed as taking the flow of products in the factory. It is given in Table 1 as a from-to chart which shows the number of products transferred between departments. From-To chart is the most helpful tool used in the analysis of material handling related to facility layout. The bigger values refer to higher relationships. Therefore, the relations are coded in letters. A shows "absolutely necessary", E is used for "especially important, and I refers to "Important".

Table 1. Flow information between departments

\begin{tabular}{|c|c|c|c|c|c|c|c|c|c|c|c|}
\hline & $\begin{array}{c}\text { Multi } \\
\text { Dimensioning }\end{array}$ & $\begin{array}{l}\text { Side } \\
\text { Cutting }\end{array}$ & $\begin{array}{c}\text { Horizontal } \\
\text { Cutting }\end{array}$ & $\begin{array}{c}\text { Honing with } \\
3 \text { heads }\end{array}$ & $\begin{array}{c}\text { Honing with } \\
4 \text { heads }\end{array}$ & $\begin{array}{l}\text { Head } \\
\text { Cutting }\end{array}$ & Washing & Drying & $\begin{array}{c}\text { Final } \\
\text { Selection }\end{array}$ & Packaging & Crating \\
\hline Selection & $\begin{array}{c}53382 \\
(E)\end{array}$ & $\begin{array}{c}58912 \\
(\mathrm{E})\end{array}$ & - & - & - & - & - & - & - & - & - \\
\hline $\begin{array}{c}\text { Multi } \\
\text { Dimensioning }\end{array}$ & - & - & $\begin{array}{c}44741 \\
\text { (I) }\end{array}$ & $\begin{array}{l}67543 \\
(E)\end{array}$ & $\begin{array}{c}19435 \\
\text { (I) }\end{array}$ & - & - & - & - & - & - \\
\hline Side Cutting & $\begin{array}{c}58903 \\
(E) \\
\end{array}$ & - & - & - & - & - & - & - & - & - & - \\
\hline $\begin{array}{c}\text { Horizontal } \\
\text { Cutting }\end{array}$ & - & - & - & $\begin{array}{c}44741 \\
\text { (I) }\end{array}$ & $\begin{array}{c}18431 \\
(\mathrm{I})\end{array}$ & - & - & - & - & - & - \\
\hline $\begin{array}{c}\text { Honing with } 3 \\
\text { heads }\end{array}$ & - & - & - & - & - & $\begin{array}{c}74417 \\
(\mathrm{E})\end{array}$ & - & - & - & - & - \\
\hline $\begin{array}{c}\text { Honing with } 4 \\
\text { heads }\end{array}$ & - & - & - & - & - & $\begin{array}{c}37866 \\
(1)\end{array}$ & - & - & - & - & - \\
\hline Head Cutting & - & - & - & - & - & - & $\begin{array}{c}112283 \\
(\mathrm{~A})\end{array}$ & - & - & - & - \\
\hline Washing & - & - & - & - & - & - & - & $\begin{array}{c}112283 \\
(\mathrm{~A})\end{array}$ & - & - & - \\
\hline Drying & - & - & - & - & - & - & - & - & $\begin{array}{c}112283 \\
(\mathrm{~A})\end{array}$ & - & - \\
\hline Final Selection & - & - & - & - & - & - & - & - & - & $\begin{array}{c}112282 \\
(A)\end{array}$ & - \\
\hline Packaging & - & - & - & - & - & - & - & - & - & - & $\begin{array}{c}112282 \\
(\mathrm{~A})\end{array}$ \\
\hline
\end{tabular}

Table 2. Distance matrix of the departments

\begin{tabular}{|c|c|c|c|c|c|c|c|c|c|c|c|c|}
\hline & $\begin{array}{c}\text { Multi } \\
\text { Dimensioning } \\
\end{array}$ & $\begin{array}{c}\text { Horizontal } \\
\text { Cutting }\end{array}$ & $\begin{array}{c}\text { Side } \\
\text { Cutting }\end{array}$ & $\begin{array}{c}\text { Honing with } \\
3 \text { heads }\end{array}$ & $\begin{array}{c}\text { Honing with } \\
4 \text { heads }\end{array}$ & $\begin{array}{l}\text { Head } \\
\text { Cutting }\end{array}$ & Washing & Drying & $\begin{array}{c}\text { Final } \\
\text { Selection }\end{array}$ & Packaging & Crating & Entrance \\
\hline Selection & $\begin{array}{l}(5.2) \\
(1.3)\end{array}$ & $\begin{array}{c}(10.07) \\
(5.2)\end{array}$ & $\begin{array}{l}(9.1) \\
(5.2)\end{array}$ & * & * & * & * & * & * & * & * & * \\
\hline $\begin{array}{c}\text { Multi } \\
\text { Dimensioning }\end{array}$ & $*$ & $\begin{array}{l}(5.52) \\
(2.6)\end{array}$ & $\begin{array}{l}(1.3) \\
(2.6) \\
\end{array}$ & $\begin{array}{l}(11.7) \\
(2.6) \\
\end{array}$ & $\begin{array}{c}(16.9) \\
(5.2) \\
\end{array}$ & * & * & * & * & * & * & * \\
\hline $\begin{array}{l}\text { Horizontal } \\
\text { Cutting }\end{array}$ & * & $*$ & $\begin{array}{l}(1.3) \\
(6.5)\end{array}$ & $\begin{array}{l}(1.3) \\
(5.2)\end{array}$ & $\begin{array}{l}(10.4) \\
(5.2)\end{array}$ & * & * & * & * & * & * & * \\
\hline Side Cutting & * & * & * & $\begin{array}{l}(9.1) \\
(3.9)\end{array}$ & $\begin{array}{l}(15.6) \\
(7.8)\end{array}$ & * & * & * & * & * & * & * \\
\hline $\begin{array}{c}\text { Honing with } \\
3 \text { heads }\end{array}$ & * & * & * & * & $\begin{array}{l}(3.9) \\
(1.3) \\
\end{array}$ & $\begin{array}{l}(1.3) \\
(1.3) \\
\end{array}$ & * & * & * & * & * & * \\
\hline $\begin{array}{cc}\begin{array}{c}\text { Honing with } \\
\text { heads }\end{array} & 4 \\
\end{array}$ & * & * & * & * & * & $\begin{array}{l}(1.3) \\
(2.6) \\
\end{array}$ & * & * & * & * & * & * \\
\hline Head Cutting & * & * & * & * & * & * & $\begin{array}{l}(3.9) \\
(1.3) \\
\end{array}$ & * & * & * & * & * \\
\hline Washing & * & * & * & * & * & * & * & $\begin{array}{l}(1.3) \\
(1.3) \\
\end{array}$ & * & * & * & * \\
\hline Drying & * & * & * & * & * & * & * & * & $\begin{array}{l}(1.3) \\
(1.3) \\
\end{array}$ & * & * & * \\
\hline Final Selection & * & * & * & * & * & * & * & * & * & $\begin{array}{l}(1.3) \\
(1.3) \\
\end{array}$ & * & * \\
\hline Packaging & * & * & * & * & * & * & * & * & * & * & $\begin{array}{l}(1.3) \\
(1.3) \\
\end{array}$ & * \\
\hline Crating & * & * & * & * & * & * & * & * & * & * & * & $\begin{array}{l}(5.2) \\
(19.5)\end{array}$ \\
\hline
\end{tabular}

The necessary distances between departments in the current layout can be seen in Table 2. The values in the first parentheses show the distances in the current layout. According to the relations and their importance, a layout is proposed and it is given in 
Figure 4. The distance matrix formed for the proposed layout can also be seen in Table 2 shown in the second parenthesis.

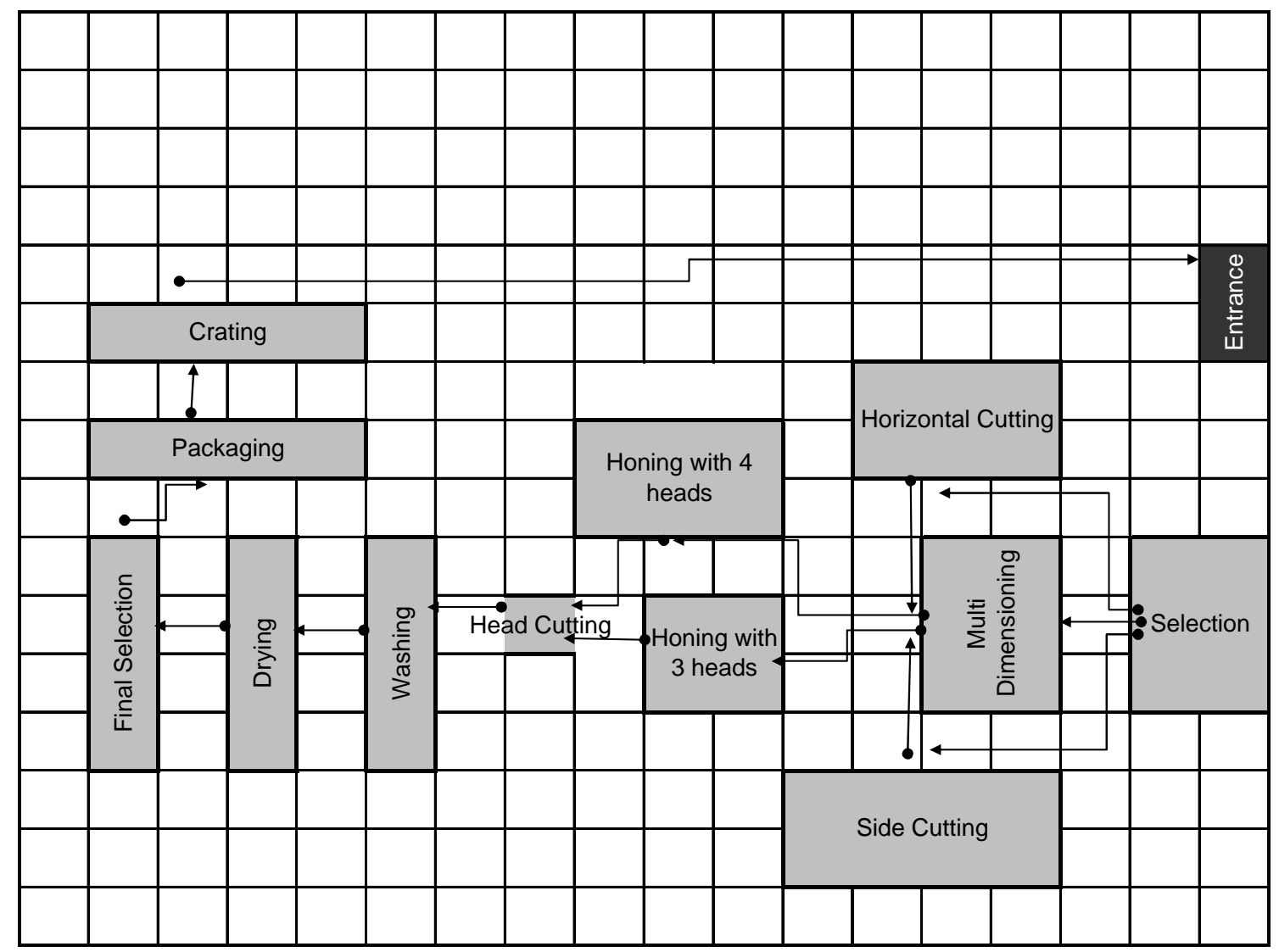

Figure 4. Proposed layout of departments

The performances of the current layout and the proposed layout are compared according to the results obtained from the simulation models. Models are simulated for $67200 \mathrm{~min}$ (70 days, $16 \mathrm{~h}$ /day) with a warm-up period of 9600 minutes (10 days, 16 $\mathrm{h}$ /day). Both models are replicated 10 times. The analysis on the unit transportation time showed that it fits a uniform distribution with Uniform $(0.5,1.2) \mathrm{min} / \mathrm{m}$. Then, the time of a transportation is calculated as proportional to the distance travelled.

Table 3. The comparison of current and proposed layouts

\begin{tabular}{|c|c|c|c|}
\hline & Current & Proposed & Improvement (\%) \\
\hline Total transportation time (min.) & 2788000 & 1261900 & 55 \\
\hline Average transportation time per product (min.) & 34.52 & 14.02 & 59 \\
\hline Total amount of final products & 50085 & 62727 & 25 \\
\hline
\end{tabular}

The comparison of current and proposed layouts is given in Table 3. As seen, the performance of the proposed model is better than the current one. The proposed layout reduces the average and total transportation time of a product through the system. 
By the proposed layout, total transportation time is improved $55 \%$ in comparison to the current layout. Also, the average transportation time per product is reduced from 34.52 to 14.02 with $59 \%$ improvement.

As the average and total transportation times are reduced in the proposed model, the productivity of the system is increased. The gained transportation times are used to produce $25 \%$ more products.

\section{CONCLUDING REMARKS}

A facility layout in a marble factory is analyzed and an alternative layout is proposed by taking the relations and the flow information of departments into account. In the analysis and comparisons, the simulation models of the current and proposed layouts are used. The proposed layout reduces the total transportation time and also the cost of transportation. Since the total transportation time is reduced, the productivity of the system is increased.

In the modeling part of the system, it is assumed that there is infinite number of transporters or workers for the transportation operations. Additionally, the products are transported from one machine to other one by one. These assumptions do not change the better performance of the proposed layout. In the further studies, the number of products transferred between departments or the required number of transporters or workers can be optimized again by using the simulation technique.

\section{REFERENCES}

1. T. Onargan, H. Köse, and A.H. Deliormanl1, Marble (third press), Turkish Mining Engineering Chamber Publications, Ankara, 2005.

2. A.I. Sönmez, Production plant design with applications, University of Gaziantep Publications, 1998.

3. A. Kusiak, and S.S. Heragu, The facility layout problem, European Journal of Operational Research 29(3), 229-251, 1987.

4. B.K. Kaku, G.L. Thompson, and T.E. Morton, A hybrid heuristic for the facilities layout problem, Computers \& Operations Research 18(3), 241-253, 1991.

5. K.R. Kumar, G.C. Hadjinicola, and T. Lin, A heuristic procedure for the single-row facility layout problem, European Journal of Operational Research 87(1), 65-73, 1995.

6. K. Tsuchiya, S. Bharitkar, and Y. Takefuji, A neural network approach to facility layout problems, European Journal of Operational Research 89(3), 556-563, 1996.

7. S.P. Singh, Solving facility layout problem: three-level tabu search metaheuristic approach, International Journal of Recent Trends in Engineering 1(1), 73, 2009.

8. R. Sharpe, and B.S. Marksjö, Solution of the facilities layout problem by simulated annealing, Computers, Environment and Urban Systems 11(4), 147-154, 1986.

9. R.R. Levary, and S. Kalchik, Facilities layout-A survey of solution procedures, Computers \& Industrial Engineering 9(2), 141-148, 1985.

10. S. Benjafaar, S.S. Heragu, and S.A. Irani, Next generation factory layouts: research challenges and recent progress, Interfaces 32(6), 58-76, 2002.

11. ARENA, User's Guide, Publication ARENA-UB001B-EN-P, October 2005. 